\title{
Salomon Ibn Gabirol
}

\author{
Cláudio Feldman*
}

Santo André, Brasil

claudiofeldman@uol.com.br

O Homem deve aspirar ao saber e assim se adentrará em tudo e o submeterá à sua autoridade. O saber conduz à atividade, afasta os elementos destruidores do espírito, rompe a obscuridade e utiliza o poder do Homem para a elaboração de uma melhor manhã em benefício do povo e da humanidade.

(Salomon Ibn Gabirol)

Durante séculos, cristãos e muçulmanos disputaram a posse de Salomon Ibn Gabirol para seus domínios culturais. Os primeiros o inscreviam, sem choque com a Santa Inquisição, como um dos seus mais luminosos pensadores, enquanto os árabes o aclamavam como insuperável filósofo de sua língua e etnia.

Somente em 1846, o pesquisador franco-judeu Salomon Munk demonstrou de maneira irrefutável que Gabirol não era católico nem maometano, mas judeu sefardita, fixando também, definitivamente, seu verdadeiro nome, que variava de historiador a historiador, de tradutor de suas obras a tradutor.

Essa confusão, segundo Munk, foi alimentada, pois o principal livro de Gabirol: A fonte da vida (Mekor Haim) foi escrito em árabe. O original se perdeu e em seu lugar se conservou uma tradução latina, Fons Vitae, elaborada no século XII.

Nas edições posteriores, à versão latina, os tradutores e talvez até copiadores transformaram o nome de Gabirol em Abengebrol, Avencebrol, Avicerón ou Avicebrán, com os quais figurou nos anais filosóficos e literários até o século XIX.

Munk comparou minuciosamente essa tradução latina com fragmentos em hebraico da mesma obra, efetuados no século XIII, e assim pôde descobrir e provar que Avicebrán (e outras variantes) e Gabirol eram a mesma pessoa. Além de esclarecer que

\footnotetext{
* Professor, escritor, roteirista e membro da Academia de Letras do Brasil (Brasília).
} 


\section{Arquivo Maaravi}

os diversos nomes de Gabirol eram frutos de equívocos, ele também conseguiu estabelecer, com exatidão, que Salomon ben Ieudá ibn Gabirol nascera em Málaga, em 1021. Órfão precocemente, foi criado por Iekutiel ibn Hassan, um ilustre desconhecido, que morreu assassinado e cuja morte traumatizou seu pupilo.

Se Gabirol teve algumas compensações, como gozar algum tempo da proteção do estadista e poeta da Espanha moura, Rabi Samuel Hanaguid, a maior parte de sua vida adulta decorreu em precárias condições, com Salomon vagamundeando pelas comunidades espanholas em busca de parnassá (sustento), vindo a falecer aos trinta e poucos anos de um problema pulmonar da qual sofria desde a juventude.

Gabirol foi exilado da corrente tradicional hebraica, ainda que tenha obtido renome como um luminar da filosofia e lírica judaicas da Idade Média. Poeta cujo pessimismo terreno é, às vezes, atenuado pela glorificação celestial, produziu marcantes versos profanos e sagrados; foi um dos primeiros poetas hebreus a se utilizar da métrica árabe, de modo conciso, puro, delicado.

Até hoje, aqueles que leem, emocionados, a bela canção de "Keter Malkut" ("Coroa da Realeza"), na celebração de Col Nidrê, na noite de Yom Kippur, não suspeitam que Gabirol é o seu criador.

Esse cântico de louvor a D-us e muitos poemas do autor (cerca de 400, alguns perdidos, compilados em três volumes por Bialik-Ravnitzky) conseguiram unânime receptividade, através dos séculos, mas o mesmo não sucedeu à sua obra de pensador.

Antes de expor o motivo de tal repulsa, seria bom enumerar os componentes da citada obra: um comentário alegórico da Bíblia (só há fragmentos), um tratado ético: Tikum Midot Hanefesch (Aperfeiçoamento das qualidades da alma) e, sobretudo, A fonte da vida.

Mas por que estranha razão Gabirol, brilho maior na plêiade de Sefarad, com tanto prestígio no mundo dos gentios, é um tabu para seu próprio povo hebreu? O motivo desse silêncio receoso, dessa verdadeira segregação, é facilmente explicável: a filosofia de Salomon ibn Gabirol é, em muitos aspectos, materialista. Inspira-se na concepção cósmica do panteísmo. Liga a ideia da divindade com os reinos naturais. Entra, assim, em radical contradição com a crença monoteísta da Lei Mosaica, segundo a qual o Criador único está acima da natureza de todas as coisas criadas.

Não havia possibilidade alguma de seus contemporâneos, judeus, assimilarem as suas ideias, algumas válidas até hoje. O pensador judaico devia purgar o preço de sua ousadia de chegar até o ponto crucial da filosofia de todos os tempos: sustentar que a matéria encerra o segredo do mundo como base de tudo que existe.

Em A fonte da vida, Gabirol afirmou: "A matéria existe per si mesma, se encontra em tudo que existe, é uma e a mesma, e não muda. As mudanças são as diferentes coisas provenientes das distintas formas que a matéria adota." 
Foi além, ao proferir que a criação não é um ato único, nem uma obra terminada, senão um permanente processo, sem interrupção ou término, um "eterno fazer". Essa observação genial (e científica) foi comprovada, séculos depois, pela Dialética da Natureza.

Isso se opunha ao texto sagrado da Torá, ao livro bíblico do Gênesis, no qual está escrito que Jeová criou o mundo e seus viventes, em um ato do próprio esforço volitivo da divindade, requisitando o sábado como dia de descanso.

As ideias expostas colocaram Salomon ibn Gabirol na galeria dos hereges; apesar de seus poemas exaltarem a ideia do Criador, como em "Keter Malkut", isto não foi uma atenuante para seus adversários, os ortodoxos de concepções estáticas, que o consideraram um judeu marginal, infectado com as ideias "impuras" de Platão e de Demócrito, o grande filósofo materialista da Antiguidade.

Hoje, com o desenrolar da história, o avanço da ciência, cultura e ética, é possível se captar a profundidade do pensamento de Gabirol, que foi, inclusive, precursor de outro outsider, deserdado pelos ortodoxos de sua comunidade: Baruch de Spinoza.

Gabirol é mais um magnífico fruto desse esplendor intelectual judeu-árabe que aconteceu em Sefarad, do século IX ao XII, antecipando o Renascimento; ao lado de Avicena, Averroes, Iehudá Halevi e Maimonides, o "Platão judeu”, no dizer de Graetz, soube fundir, com sua arte e conhecimento, o saber judaico e gentio.

\section{RESUT}

Desejei-te em crepúsculos e auroras

e para ti voltei as mãos e a face.

Clamei por ti, o coração ansioso

como o mendigo que em meu pátio pede.

As alturas não bastam a conter-te

e no entanto tu habitas minhas portas.

Como não guardarei Teu nome e glória

e teu amor não hei de ver triunfante?

Eu louvarei o nome do Senhor

Enquanto o hálito seu em mim fôr vivo. ${ }^{1}$

Recebido em: 13/09/2019.

Aprovado em: 23/09/2019.

\footnotetext{
${ }^{1}$ GABIROL, Salomon ibn. Resut. Trad. Renata Pallotini. In: GUINSBURG, Jacó (Org.). Quatro mil anos de poesia. São Paulo: Perspectiva, 1969. p. 106.
} 